\title{
Biological control of strawberry crown rot is substrate dependent phenomenon
}

\author{
Juho Hautsalo ${ }^{\mathrm{a}, *}$, Mauritz Vestberg $^{\mathrm{a}}$, Päivi Parikka ${ }^{\mathrm{b}}$, Sanna Kukkonen ${ }^{\mathrm{a}}$, Saila Karhu ${ }^{\mathrm{c}}$ \\ and Risto Tahvonen ${ }^{\mathrm{c}}$ \\ ${ }^{a}$ Natural Resources Institute Finland (Luke), Green technology, Antinniementie 1, Vihtavuori, Finland \\ ${ }^{\mathrm{b}}$ Natural Resources Institute Finland (Luke), Management and Production of Renewable Resources, \\ Jokioinen, Finland \\ ${ }^{\mathrm{c}}$ Natural Resources Institute Finland (Luke), Management and Production of Renewable Resources, \\ Toivonlinnantie 518, Piikkiö, Finland
}

Received 14 July 2015; accepted 26 october 2015

\begin{abstract}
.
BACKGROUND: Phytophthora cactorum crown rot is currently limiting strawberry cultivation worldwide. Arbuscular mycorrhizal fungi (AMF) and bacterial endophytes have shown promising results as biological control against the disease. Growing medium can also influence biological control and e.g., composts have been shown to suppress soil borne pathogens. OBJECTIVE: The aim of the study was to investigate the effect of AMF, endophytic bacteria and different growing media against strawberry crown rot.

METHODS: Three pot experiments were conducted in greenhouse conditions. Each experiment tested different biological control methods with micropropagated strawberry 'Jonsok' inoculated or not with the fungus. The first experiment evaluated AMF strains on different growing media, the second experiment tested combinations of AMF and other biocontrol microbes. The third experiment tested the impacts of AMF, Pseudomonas fluorescens and compost.

RESULTS: Biological control methods and disease inoculation had very different impacts on strawberries planted in different growing media. On suitable growing media, AMF increased growth and lowered disease symptoms, but P. fluorescens was not effective. The growing medium containing manure/wood fiber compost was the most disease suppressive.

CONCLUSIONS: Biological control of strawberry crown rot with AMF is substrate dependent. Composts can be used to somewhat suppress crown rot.

Keywords: Fragaria, Phytophthora cactorum, biocontrol, mycorrhiza, compost

\section{Introduction}

The soil borne Phytophthora cactorum (Lebert and Kohn) is a fungal pathogen of a number of globally important crops. It causes leather rot on fruits and crown rot and wilt [1] in cultivated strawberry, Fragaria $\times$ ananassa Duch. Affected strawberry plants wilt, turn brown and die. Since the first report of the disease on strawberry in 1954 [2], crown rot has become a limiting factor in successful strawberry production worldwide and it has also become established in Finnish strawberry fields since 1990 [3]. Once this soil-borne pathogen has infested the soil, the oospores are difficult to eradicate and can persist for many years and spread easily during wet periods also on transported fruit [1].
\end{abstract}

\footnotetext{
${ }^{*}$ Corresponding author: Juho Hautsalo, Natural Resources Institute Finland (Luke), Green technology, Antinniementie 1, FI-41330 Vihtavuori, Finland. Tel.: +358 295326678; E-mail: juho.hautsalo@luke.fi.
} 
After the use of the soil fumigation agent methyl bromide (MB) was banned by the Montreal protocol [4], chemical protection against soil-borne diseases of strawberry has relied on less environmentally hazardous chemicals such as 1,3-dichloropropene or methyl iodine. These are however usually less efficient than MB and are therefore combined to achieve a better management [5]. Consequently, biological control has become more realistic as an alternative to chemical control. When biological control is combined with planting resistant cultivars (screened for Finnish conditions since 1993 [6]), healthy propagation material and good cultural practices such as planting in disease-suppressive substrates, it becomes a competitive choice to restrain disease outbreaks.

More than $80 \%$ of land-living plant species form a symbiotic relationship with arbuscular mycorrhizal fungi (AMF) that taxonomically belong to the phylum Glomeromycota [7]. The AMF not only improve nutrient and water uptake of the plants but also have the potential to protect them against biotic stress caused by nematodes and soil-borne plant pathogens [8]. AMF inoculation has been shown to reduce symptoms of soil-borne disease caused by several pathogens such as Pythium in several crops including papaya [9] and tomato [10]. In strawberry, AMF inoculation has been noted to reduce disease severity of red stele root rot caused by $P$. fragariae var. fragariae, $[11,12])$ and crown rot (caused by P. cactorum, [13]).

Plant-growth-promoting rhizobacteria (PGPR) have been shown to decrease disease incidence of strawberry crown rot [14, 15]. The bacteria Bacillus amyloliquefaciens, Pseudomonas fluorescens and Raoultella terrigena have even been shown to have an effect on plant pathogens comparable to the use of chemical fungicide [16]. Agusti et al. [17] also found that combining different Pseudomonas fluorescens strains enhanced biocontrol stability significantly against Phytophthora cactorum root rot under greenhouse conditions. Pseudomonas spp. can also be found inside the plants and, although it has not been found in micropropagated strawberry, it is one of the most common endophytic genera, together with Pantoea [18], associated with strawberry. In vitro studies at MTT Agrifood Research Finland (MTT), Piikkiö have shown that endophytic P. fluorescens isolated from strawberry has the potential to decrease the damage caused by crown rot and grey mold of strawberry [19].

In disease control, composition of the growing medium should also be considered. For example, composts are good soil conditioners, but they have also been shown to have an impact on several soil borne pathogens such as Pythium [20, 21], Phytophthora [20, 22] and Fusarium [23]. Seven out of 21 Finnish commercial composts showed disease suppressiveness against Phytophthora in strawberry and Pythium in cucumber [20]. In general disease suppressiveness can be attributed to the overall microbial activity of the compost, which is related to decomposition level. Too immature composts may contain phytotoxic compounds such as polyphenols [24] as well as pathogen growth-promoting compounds such as glucose [25]. When decomposition continues too far compost's suppressiveness may disappear. For example, dark, decomposed, sphagnum peat has very low microbial activity which makes it conducive to plant pathogens [26].

There are no reports on the effects of several introduced antagonists together with disease suppressive compost in biological control of strawberry crown rot, although composts have been shown to contain several antagonistic species [22] and the positive suppressive effects of combining fungal and bacterial antagonists have been discussed and studied [27, 20]. In this study the standalone and joint effects of various microbial inoculations were compared on several growing media and disease development of Phytophthora cactorum and the growth response of strawberry were evaluated. Finnish expertise, microbiological products and composts were applied to gain new information on biological plant protection. The first aim of our study was to find suitable bacterial and fungal isolates that could be used to protect strawberry plants against $P$. cactorum. The second aim was to test the interactions of different microbes together with disease suppressive compost on strawberries infested with crown rot disease.

\section{Material and methods}

\subsection{General experimental setup}

Three separate greenhouse pot experiments were carried out at Natural Resources Institute Finland (Luke), Jokioinen. Two experiments were conducted in 2012 and the third one in 2013 (Table 1). The experiments 
Table 1

Experimental details. Experiment duration (weeks) can be split into the inoculation period of mycorrhiza and Pseudomonas and to Phytophthora inoculation period

\begin{tabular}{lccc}
\hline & Experiment 1 & Experiment 2 & Experiment 3 \\
\hline Design & split-split-plot & split-plot & split-split-plot \\
Repeats & 8 & 6 & 6 \\
Main plots & 3 & 2 & 3 \\
Sub plots & 2 & 14 & 4 \\
sub-sub plots & 4 & - & 2 \\
Total number of pots & 192 & 168 & 144 \\
Starting date & 10.4 .2012 & 17.9 .2012 & 7.8 .2013 \\
Duration of the entire experiment & 11 & 10 & 10 \\
Duration of Phytophthora inoculation & 6 & 5 & 6 \\
AMF strains & 3 & 2 & 1 \\
Bacterial strains & 0 & 2 & 1 \\
Composts & 0 & 0 & 3 \\
\hline
\end{tabular}

Six replications were used for the disease inoculation experiment and two replications for checking the AMF inoculation success in Experiment 1.

had a duration of 9 to 11 weeks. The first experiment tested the disease control effect of three AMF on three growing media. In the second experiment, single, dual or triple inoculation with AMF isolates, plant endophytic bacteria and the biocontrol product Prestop ${ }^{\circledR}$ were tested. In the third experiment, effects of one AMF and one endophytic bacterium were tested on growing media amended or not with disease suppressive compost. Based on their chronological order, these experiments are from here on referred to as Experiment 1, Experiment 2 and Experiment 3. All experiments used microplants of the cultivar Jonsok that had been produced and grown at the Laukaa Unit of Luke. The experiments were carried out in two phases. In phase one, the strawberry microplants were first acclimatized in a growth chamber at Laukaa $\left(20^{\circ} \mathrm{C}\right.$, photoperiod: $16 \mathrm{~h} \mathrm{light}\left(70 \mu \mathrm{mol} / \mathrm{m}^{2} / \mathrm{s}\right) 8 \mathrm{~h}$ dark $)$. Inoculation of beneficial microorganisms was done at the beginning of this phase. The microplants were grouped into three sizes (small, middle-size, large) that were used for planting in certain replications to minimize variation caused by size difference. For the first 10 days after planting the microplants were acclimatized under a plastic cover. In phase 2, at the age of 4-5 weeks, acclimatized plants were delivered to Luke at Jokioinen where they were inoculated or not with Phytophthora cactorum. Half of the plants that were control plants that were not inoculated with Phytophthora but were grown in same conditions with inoculated plants. In experiments 1 and 2 the plants were grown in plastic pots (Vefi AG, Norway) containing approximately 0.2 liters of growing medium. In Experiment 3, one-liter pots were used (Pöppelmann, Germany). The plants were watered when needed. The temperature in the greenhouse was kept at $20 \pm 2{ }^{\circ} \mathrm{C}$ during the pathogen inoculation period and after that the day temperature was raised to $23^{\circ} \mathrm{C}$ (night temperature $18^{\circ} \mathrm{C}$ ). During phase two the light intensity was kept above $200 \mathrm{~W} / \mathrm{m}^{2} 16 \mathrm{~h}$ per day with the help of high-pressure sodium lamps.

\subsection{Phytophthora inoculation}

Phytophthora cactorum was cultured on potato dextrose agar (PDA) plates at room temperature. The culture consisted of four isolates of Phytophthora that had been isolated from Finnish berry fields in the early $1990 \mathrm{~s}$. The isolates were given identification numbers 5, 18, 23 and 38. They had all been found to belong to the European population of $P$. cactorum. When the plates were covered with fungal mycelium they were transferred to $6-7^{\circ} \mathrm{C}$. At the age of 3 weeks or more, $20 \mathrm{ml}$ of sterile water was added to each plate whereafter the plates were kept at room temperature. The Phytophthora suspension was prepared by using a glass rod to transfer fungal mycelium 
and water from the agar plates into another vessel, in which the mycelium was homogenized. The concentration of zoosporangia in the suspension was determined with a hemacytometer and it was on average $1.5-2.0 \times 10^{5}$ per $\mathrm{ml}$. Five weeks after the onset of the experiment $40 \mathrm{ml}$ of the Phytophthora suspension was poured into each strawberry pot except control pots.

\subsection{Biological disease management organisms}

The following AMF strains were tested in Experiment 1: Claroideoglomus claroideum BEG31, Glomus hoi V307 and Myko-Ymppi (Rhizophagus intraradices, produced at MTT, Laukaa in 2012). Of these, BEG31 and Myko-Ymppi were used in Experiment 2 while for Experiment 3, only Myko-Ymppi was chosen. Endophytic bacteria applied were Pseudomonas fluorescens strain PsF (Experiment 2) and P. fluorescens strain PsA (experiments 2 and 3). In Experiment 2, also Prestop ${ }^{\circledR}$ (Verdera Oy, Finland), a product containing spores of the fungus strain Gliocladium catenulatem J1446, was tested using a concentration of $500 \mathrm{~g} / \mathrm{m}^{3}$.

Prior to use in experiments, the AMF-strains were propagated each year in pots with Plantago lanceolata for 2.5 months using a sand + attapulgite clay (Agsorb, Oil-Dri, UK) growing medium that favors mycorrhizal development and spore production (Growing medium M, Table 2). The ready AMF inoculant, which contained mycorrhizal structures like spores, hyphae and infected root pieces, together with the initial growing medium, was mixed with the experimental growing medium at a volume of 5\%. The percentage of AMF colonization of roots was determined from inoculated pots at the end of each experiment. The determination of AMF colonization was done under a dissecting microscope by using the grid-line intersect method [28] with $0.05 \%$ methyl blue staining [29].

Pseudomonas strains taken from frozen stock were grown on King B agar [30] plates sealed with Parafilm ${ }^{\circledR}$ and incubated upside-down overnight at $26^{\circ} \mathrm{C}$ until colonies became visible. Then a liquid bacterial culture was prepared for strawberry plant inoculation by transferring a loop-full of bacteria to $25 \mathrm{ml}$ of liquid King B and incubating overnight at $26^{\circ} \mathrm{C}$ on a shaker $(250-300 \mathrm{rpm})$. After that the cell density was estimated by using a spectrophotometer (Nanodrop 2000c, Nanodrop products, USA) at a light density of $600 \mathrm{~nm}$ (absorbance of 1.6

Table 2

The growing media used in the experiments

\begin{tabular}{|c|c|c|c|c|c|c|c|}
\hline Growing medium* & M & A & B & $\mathrm{C}$ & $\mathrm{D}$ & $\mathrm{E}$ & $\mathrm{F}$ \\
\hline Experiment & - & $1 \& 2$ & 1 & 1 & 3 & 3 & 3 \\
\hline \multicolumn{8}{|l|}{ Ingredients } \\
\hline Sterile sand $\%$ & 50 & 75 & 40 & 50 & 16.7 & 16.7 & 16.7 \\
\hline Kaolin $\%$ & - & 10 & - & - & - & - & - \\
\hline Sterile dark peat $\%$ & - & 5 & 20 & - & 66.7 & 66.7 & 83.3 \\
\hline Perlite \% & - & 10 & 30 & - & - & - & - \\
\hline Bara-clay (Bara Mineraler AG, Sweden) $\%$ & - & - & 10 & - & - & - & - \\
\hline Agsorb (Oil-Dri, UK) & 50 & - & - & 50 & - & - & - \\
\hline Compost \% & - & - & - & - & 16.7 & 16.7 & - \\
\hline Dolomite lime $\mathrm{g} / \mathrm{l}$ & 5 & 0.4 & 0.1 & 0.1 & 5.3 & 6.6 & 8.3 \\
\hline Puutarhan Y1, (9N-6P-17K, Yara Suomi Oy, Finland) g/l & - & - & - & - & 0.4 & 0.4 & 0.4 \\
\hline Puutarhan NK, (13N-0P-11K, Yara Suomi, Finland) g/l & - & - & - & - & 0.9 & 0.9 & 1.1 \\
\hline OsmocotePlus, (16N-3P-10K, Everris, The Netherlands) g/l & - & 1 & 1 & - & - & - & - \\
\hline
\end{tabular}

$* \mathrm{M}=$ Medium optimized for AMF inoculum production, $\mathrm{A}=$ Modified bioassay medium, $\mathrm{B}=$ Medium optimized for AMF colonization, $\mathrm{C}=$ Medium favoring AMF colonization and spore formation, $\mathrm{D}=$ Medium containing manure/wood fiber compost, $\mathrm{E}=\mathrm{Medium}$ containing sewage sludge compost, $\mathrm{F}=$ control without compost. 
corresponds to $10^{9}$ Colony Forming Units (CFU) $\mathrm{ml}^{-1}$ suspension). Before acclimatization, rooted microplants were inoculated by dipping their roots for 5 seconds in the bacterial suspension of $P$. fluorescens $\operatorname{PsF}\left(10^{6} \mathrm{CFU}\right.$ $\left.\mathrm{ml}^{-1}\right)$ or $P$. fluorescens PsA $\left(10^{3} \mathrm{CFU} \mathrm{ml}{ }^{-1}\right)$.

\subsection{Growing media and compost amendments}

In Experiment 1 three different growing media were tested (A, B and $\mathrm{C}$ in Table 2) of which medium $\mathrm{A}$ was also used in Experiment 2. Medium A was a modified artificial soil for bioassays [31], while medium B was an optimized medium for AMF colonization [32] and medium $C$ had favored AMF colonization and spore formation in earlier studies [33]. In Experiment 3 there were also three media (D, E, F, Table 2) but with different compost amendments. Medium D contained manure/wood fiber compost (Humuspehtoori Oy, Finland) made from chicken and horse manure plus wood industrial residue, whereas sewage sludge compost with peat and wood chips (Mustankorkea Oy, Finland) was used in medium E. Growing medium F was a control medium without compost. The composts in Experiment 3 had been suppressive against $P$. cactorum in a previously reported comparison of commercially produced composts in Finland [20].

The $\mathrm{pH}$ of various growing media was adjusted to $6-6.5$ by using $0.1-8.3 \mathrm{~g}$ Dolomite lime growing medium $1^{-1}$ (Table 2). The amounts of available nutrients were targeted to about $250 \mathrm{mg} \mathrm{N}, 30 \mathrm{mg} \mathrm{P}$ and $150 \mathrm{mg} \mathrm{K}$. These values are close to those recommended for commercial strawberry cultivation. In reality, however, the mineralization of nutrients in the various growing media was probably somewhat different. The composts of growing media $\mathrm{D}$ and $\mathrm{E}$ contained significant levels of total nitrogen and phosphorus. Nitrogen was also certainly mobilized from the dark peat used in D, E and F. Mobilization of N, P and K nutrients from Agsorb and Osmocote Plus is also hard to predict. Due to all these factors, the different growing media had somewhat different levels of available nutrients in the three experiments. The levels of available nutrients were not measured at the end of experiments.

\subsection{Experimental design}

The experimental setup of all three experiments can be seen in Table 1. In Experiment 1, the split-split-plot experimental design was used to test the biological control of $P$. cactorum with AMF on three different growing media. Growing medium (A, B or C, Table 1) was the main plot, disease inoculation (inoculated or not with $P$. cactorum) the subplot and AMF (inoculated or not with AMF) the sub-subplot. A growing medium containing Plantago lanceolata roots, but no AMF, was used as the non-mycorrhizal control in the sub-sub-plots.

In Experiment 2, the split-plot design was used to test the control of P. cactorum with AMF and endophytic bacteria. Disease inoculation (inoculated or not with $P$. cactorum) was the main plot and microbial inoculation (13 single and dual inoculations and an untreated control) the subplot (Table 1). The microbial inoculations included the Prestop ${ }^{\circledR}$-product, two strains of endophytic bacteria, two AMF strains and their combinations. The most suitable growing medium for mycorrhiza from Experiment 1 was applied also in Experiment 2.

In Experiment 3, a split-split-plot design was applied for testing the control of P. cactorum by using AMF, endophytic bacteria and disease suppressive composts. Compost treatment (compost or no compost, growing media D, E, and F, Table 2) was the main plot, microbial inoculation (including Myko-Ymppi, P. fluorescens, a combination of these and a control) was the sub-plot and disease inoculation (inoculated or not with P. cactorum) was the sub-subplot.

\subsection{Observations}

The vigor of the plant shoots was visually judged weekly on a rating scale from 0 to 5 ( 0 being dead and 5 being healthy). Disease severity was assessed by root and crown discoloration from P. cactorum-inoculated 
plants at the end of the experiment. The scale was from 0 to 1 for crowns ( 0.1 accuracy) and 0 to 3 ( 0.5 accuracy) for roots. Zero indicated healthy and 1 (crown) or 3 (roots) completely rotten. Plant height, leaf numbers and size were also measured weekly, but this data is not presented here. At the end of each experiment, the fresh and dry shoot weights of mother and runner plants were measured.

\subsection{Statistical analysis}

Statistical analyses were performed by using the mixed models procedure of the SAS Enterprise Guide 5.1 (SAS Institute Inc., Cary, NC, USA). The analysis of variance was based on the common mixed model for a splitplot or split-split-plot designs. In Experiment 1 growing medium was set as a whole-plot factor. In Experiment 2 the same procedure was done for Phytophthora inoculation and in Experiment 3 for compost. Sub-factors were Phytophthora inoculation in Experiment 1 and microbial inoculation in Experiments 2 and 3. In the first and third experiment there were also sub-sub-factors, which were AMF strain and Phytophthora treatment, respectively. Replication was set as a random (blocking) factor in all experiments. Pairwise comparisons were performed by two-sided t-type tests for Experiments 1 and 3. The Tukey-Kramer adjustment was applied in Experiment 3 to lower the risk caused by high number of $t$-tests. Model assumptions were checked graphically. Equality of variances was visually judged by plotting residuals against fitted values and normality of the variables by inspecting model residuals in a normal probability.

\section{Results and discussion}

\subsection{Plant vigor and disease development}

Development of plant vigor after Phytophthora inoculation varied within and between experiments, but the median vigor of non-inoculated plants remained constant at 5 (completely healthy) indicating that the disease was the only factor that clearly caused decreased vigor. Plant vigor gives information about the general condition of the plant and the disease symptoms. Since it was observed weekly, the possible time differences in disease emergence between treatments can be seen. Another way to evaluate crown rot symptoms is the root and crown discoloration assessment (Table 3). This partly supported the vigor results, although the root and crown disease symptoms were not as clearly distinguishable.

Experiments 1 and 3 showed clear differences between treatments and growing media in the weekly development of median vigor during the Phytophthora infestation stage (Fig. 1). The differences due to the growing medium can be seen in both experiments. Using growing medium A (Fig. 1) the decrease in vigor is clearly slower for mycorrhiza-treated plants than for control plants. Therefore this growing medium was selected for Experiment 2. The mycorrhiza treatments in growing medium A had also lower crown discolorations when compared to the control (Table 3), but the differences in root discoloration were negligible. Similar observations of vigor development were made from growing medium B but with an overall faster decrease of shoot vigor (Fig. 1). Root and crown symptoms were also severe on growing medium B compared to C (Table 3), but these observations do not support the positive impact of AMF inoculations on growing medium A, although the treatment with strain V307 lowered root symptoms slightly. Growing medium B was a 2:1 mixture of sterilized peat and sand (Table 2). It was quite conducive to Phytophthora attack resulting in an overall rapid decrease of strawberry vigor (Fig. 1) with small differences between AMF strains and the control. This result is in agreement with an earlier study by Vestberg et al. [34] in which a similar kind of growing medium also resulted in small differences between AMF strains and the control suggesting that this type of growing medium is not optimal for functional biocontrol, although it is designed for maximal AMF colonization [32].

On medium $\mathrm{C}$, the differences were not as clear as with $\mathrm{A}$ and $\mathrm{B}$ but the overall vigor remained at the highest value. Growing medium $\mathrm{C}$ showed few disease symptoms with no crown rot symptoms at all and low root 
Table 3

Medians $(N=6)$ of crown (scale $0-1 ; 0=$ healthy, $1=$ strongly discolored) and root health (scale $0-3,0=$ healthy, $3=$ strongly discolored) of Phytophthora-inoculated 'Jonsok' microplants growing in media A-F (see Table 1) and given various microbial treatments in three experiments. Crown and root health were assessed at the end of each experiment

\begin{tabular}{|c|c|c|c|c|}
\hline Experiment & Growing medium & Treatment & Crown health & Root health \\
\hline \multirow[t]{12}{*}{1} & A & Control & 0,8 & 2,5 \\
\hline & & Claroideoglomus claroideum BEG31 & 0,6 & 3 \\
\hline & & Glomus hoi $\mathrm{V} 307$ & 0 & 3 \\
\hline & & Myko-Ymppi ${ }^{\circledR}$ & 0,3 & 2,5 \\
\hline & B & Control & 1 & 3 \\
\hline & & C. claroideum BEG31 & 0,8 & 3 \\
\hline & & G. hoi V307 & 0,8 & 1 \\
\hline & & Myko-Ymppi ${ }^{\circledR}$ & 1 & 3 \\
\hline & $\mathrm{C}$ & Control & 0,1 & 1,5 \\
\hline & & C. claroideum BEG31 & 0 & 1 \\
\hline & & G. hoi $\mathrm{V} 307$ & 0 & 1 \\
\hline & & Myko-Ymppi ${ }^{\circledR}$ & 0,3 & 1 \\
\hline \multirow[t]{14}{*}{2} & A & 1. Control & 0 & 0,5 \\
\hline & & 2. Prestop ${ }^{\circledR}$ & 0,4 & 0,5 \\
\hline & & 3.Pseudomonas fluorescens PsF & 0,3 & 0 \\
\hline & & 4. P. fluorescens PsA & - & 0,5 \\
\hline & & 5. C. claroideum BEG31 & 0,2 & 0,5 \\
\hline & & 6. Myko-Ymppi ${ }^{\circledR}$ & 0 & 0 \\
\hline & & 7. $3+5$ & 0 & 0 \\
\hline & & $8.3+6$ & 0 & 0 \\
\hline & & 9. $4+5$ & 0,1 & 0 \\
\hline & & 10. $4+6$ & 0 & 0,5 \\
\hline & & 11. $2+7$ & 0 & 0 \\
\hline & & 12. $2+8$ & 0 & 0 \\
\hline & & 13. $2+9$ & 0,2 & 1,5 \\
\hline & & 14. $2+10$ & 0 & 0 \\
\hline \multirow[t]{12}{*}{3} & $\mathrm{D}$ & Control & 0 & 0 \\
\hline & & Myko-Ymppi ${ }^{\circledR}$ & 0 & 0 \\
\hline & & P. fluorescens PsA & 0,5 & 1,8 \\
\hline & & Myko-Ymppi ${ }^{\circledR}+$ PsA & 0,1 & 0 \\
\hline & $\mathrm{E}$ & Control & 0,3 & 0,5 \\
\hline & & Myko-Ymppi ${ }^{\circledR}$ & 0,5 & 2 \\
\hline & & P. fluorescens PsA & 0,4 & 1 \\
\hline & & Myko-Ymppi ${ }^{\circledR}+$ PsA & 1 & 3 \\
\hline & $\mathrm{F}$ & Control & 1 & 3 \\
\hline & & Myko-Ymppi ${ }^{\circledR}$ & 1 & 3 \\
\hline & & P. fluorescens PsA & 1 & 3 \\
\hline & & Myko-Ymppi ${ }^{\circledR}+$ PsA & 0,4 & 2 \\
\hline
\end{tabular}


discoloration symptoms (Table 3). The growth of strawberry was here significantly weaker, probably due to lower nutrient availability on this growing medium compared to growing media A and B (next chapter). In comparison with the control, the differences in plant vigor after inoculation with different AMF strains were also small (Fig. 1).

Composts in Experiment 3 delayed the weakening of vigor when compared to the control (Fig. 1, growing media $D$ and $E$ vs. F) and this result is also supported by the lower root and crown symptoms (Table 3 ). However, all microbial treatments, except the combination of Myko-Ymppi and Pseudomonas fluorescens on the manure/wood fiber compost medium resulted in a faster decrease of vigor than the control. Especially the Pseudomonas treatment seemed to accelerate the weakening of vigor and increase both root and crown discoloration (Table 3). There are reports of negative endophytic activity in changed conditions such as re-inoculation and it has been suggested that this may be due to an unbalanced equilibrium between the host and a bacterial endophyte [35]. Most of the microbial inoculations in Experiment 3 seemed to increase the symptom development in the shoots and caused more severe symptoms in roots and crowns also (Table 3), which is an unwanted result. Similar results were obtained also by Davis and Menge [36] in citrus, where AMF-inoculated plants correlated positively with soil phosphorous levels and susceptibility to Phytophthora root rot. The high nutrient levels of compostamended growing media, in particular the one containing sewage sludge, caused abundant strawberry growth although this growing medium was probably suboptimal for the function of the mycorrhiza. It is a well-known fact that the impacts of mycorrhiza can turn negative at high soil phosporus, which has been shown also for strawberry [37]. From this point of view, the negative impact of microbial inoculants at high nutrient levels is quite logical.

The use of manure/wood fiber compost (Fig. 1, growing medium D) resulted in the highest overall plant vigor, which shows that this growing medium can suppress $P$. cactorum. This compost has been shown to be suppressive against Phytophthora and Pythium also earlier [38]. The compost-amended growing media E was also suppressive against $P$. cactorum but to a lower degree than growing medium D (Fig. 1, Table 3 ). Disease suppressive composts are being studied largely worldwide and have a great potential as a biological control method against plant diseases [20-23], but there are also problems with their use. The problems are usually related to inconsistent performance as was also shown in our previous study [20] where the suppressiveness varied between the plant species and compost used. Biowastes are often used as compost, but they are heterogeneous products that often cause unstable disease suppressiveness of the end-product. Dark peat was the main ingredient in the growing media in Experiment 3 (Table 2). This is a peat quality which has been used also in our previous microbial experiments with promising results [13] due to the disease conducive nature of dark peat [39].

Since the most of the treatments were quite healthy the symptom development in Experiment 2 suggests that the disease inoculation was not successful (Table 3). In Experiment 2 the only treatment that affected median vigor during the five-week disease inoculation period was the Prestop ${ }^{\circledR}$ treatment, which lowered the median vigor rating from 5 to 2 two weeks after Phytophthora inoculation. When Prestop ${ }^{\circledR}$ was combined with AMF and Pseudomonas treatments the median vigor remained equal to the control (completely healthy). The disease increasing effect of Gliocladium catelatum (Prestop ${ }^{\circledR}$ ) does not support its use as a biological control agent against $P$. cactorum and should be further studied. However no statistical analysis of these results could be made and therefore they remain merely directional.

\subsection{Shoot dry weight}

A clear correlation was found between the number of fully developed leaves and dry weight $(r>0.45$, data not shown) as well as between plant height and dry matter content $(r>0.69$, data not shown) in all experiments and also between dry weight and plant vigor in Experiments 1 and $3(r>0.48)$. Statistical analyses of dry weight give a relevant description of growth under different treatments in all three experiments.

Significant effects of growing medium and Phytophthora inoculation and their interaction, but not of mycorrhizal inoculation, on dry weight were found on strawberry in Experiment 1 (Fig. 2). As can be seen from Fig. 2, 

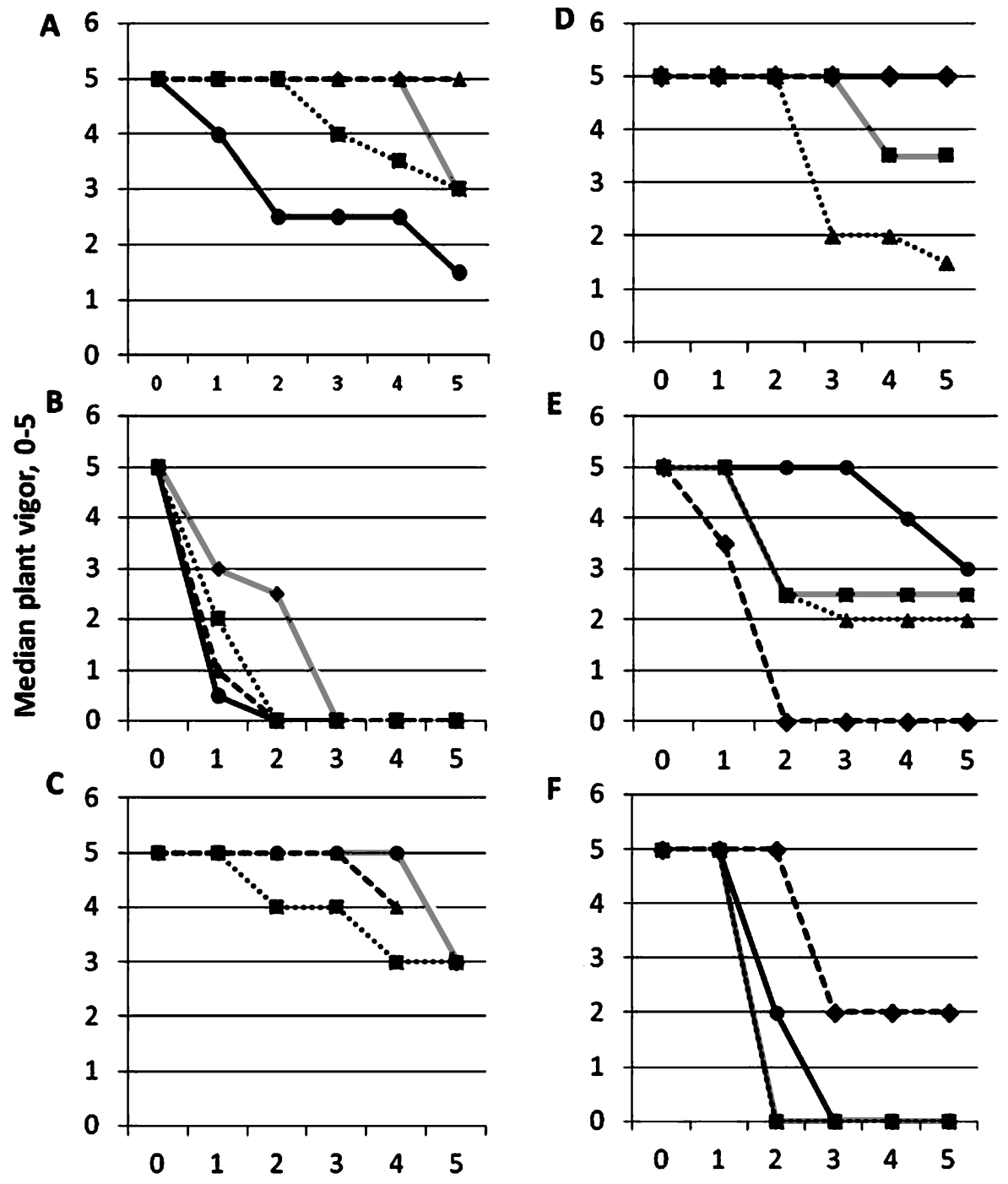

Weeks after Phytophthora inoculation

Weeks after Phytophthora inoculation
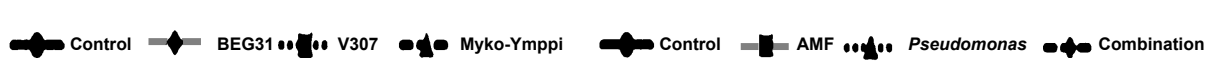

Fig. 1. Weekly development of median plant vigor in Phytophthora inoculated plants $(N=6)$ in Experiments 1 and 3 on different growing media (A,B and C in Experiment 1 and D, E, and F in experiment 3) and under different treatments (3 AMF strains and a control without AMF inoculation in Experiment 1 and endophytic bacteria, AMF strain, their combination and a control without AMF or endophyte inoculation in experiment 3). Growing media described in Table 2. Myko-Ymppi treatment's values on growing medium $\mathrm{C}$ are missing in the last observation.

and also from the pairwise comparisons by $t$-tests, the Phytophthora inoculation caused a significant dry weight reduction on growing medium $\mathrm{A}(\mathrm{df}=18.5, t=5.68, p<0.0001)$ and $\mathrm{B}(\mathrm{df}=18.5, t=11.96, p<0.0001)$, but not on $\mathrm{C}(\mathrm{df}=18.5, t=0.39, p=0.7007)$. However the growth reduction was less severe in Phytophthora-treated 


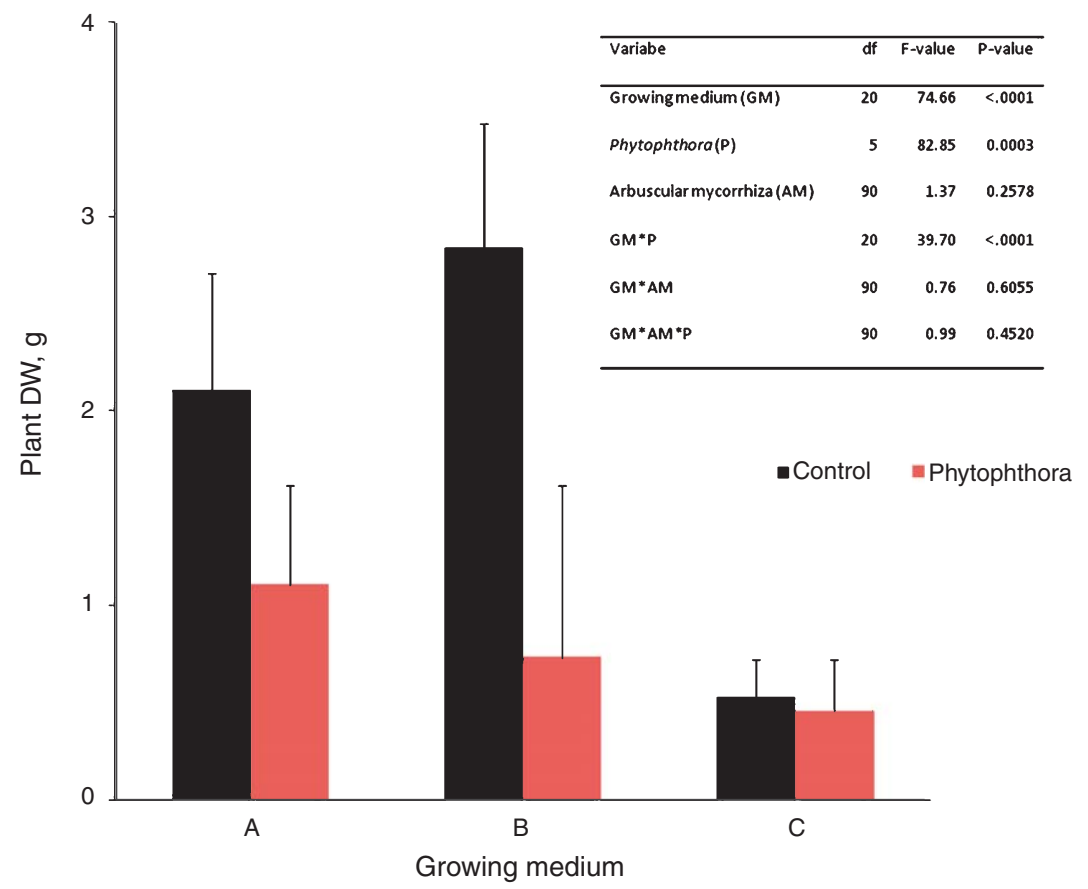

Fig. 2. The impact of $P$. cactorum inoculation vs. control on shoot dry weight (DW) of 'Jonsok' strawberries (mean+std; $N=32)$ growing on three growing media (experiment 1 , see Tables $1 \& 2$ ). The results are means of three microbial and a control treatment. The Figure also includes the mixed model analysis of dry weight variance in the experiment.

strawberries on growing medium A than on the other growing media. These results are also supported by our findings of disease symptom development described above and indicate that biological control of strawberry crown rot is controlled by the growing medium.

In Experiment 2, only Phytophthora inoculation (Table 4) had a significant impact on the growth of strawberry, thus no significant differences between different biological control organisms and their combinations could be shown regarding plant growth, although dual inoculations seemed to have slightly better growth than single or triple inoculations (data not shown). At the end of the experiment the average dry weight of control plants was $4.09 \mathrm{~g}(\mathrm{std}=0.96)$ and for the Phytophthora-inoculated plants $3.72 \mathrm{~g}(\mathrm{std}=1.04)$. The average growth reduction caused by the disease $(10 \%)$ was relatively low in this experiment and although it was narrowly significant $(\mathrm{df}=1$, $t=5.88, p=0.0167$ ), it supports our previous conclusion that disease inoculation had not been very successful. Disease inoculation is challenging and success is dependent on the method used as well as the environmental conditions. The fact that Experiment 2 was conducted in the autumn possibly influenced the aggressiveness of the pathogen and might have also had an impact on the existing micro-organisms. Crown rot infection requires

Table 4

Mixed model analysis of dry weight variance in Experiment 2

\begin{tabular}{lccr}
\hline Variable & df & F-value & $P$-value \\
\hline Phytophthora & 135 & 5.88 & 0.0167 \\
Microbial treatment & 135 & 0.77 & 0.6855 \\
Microbial treatment*Phytophthora & 135 & 1.23 & 0.2626 \\
\hline
\end{tabular}


wet and warm conditions, but the optimum environment for disease development is in hot and dry conditions [1]. The number of oospores per $\mathrm{cm}$ of root in autumn was much lower than in summer in a previous study of ours [13]. The same experiments also gave much more support to the positive effects of micro-organisms during early-summer than during late-summer and autumn experiments. The reason for this probably lies in differences in the physiological statuses of the strawberry roots [13].

In Experiment 3, Phytophthora inoculation decreased strawberry growth by 55\% in the control treatment of growing medium F. In the media amended with compost the corresponding growth decrease was $20 \%$ and $21 \%$ for manure/wood fiber compost and sewage sludge compost, respectively. The dry weights at the end of the experiment were significantly affected by the compost amended, the microbial treatment and Phytophthora inoculation. Significant compost*microbe and compost*Phytophthora interactions were also detected (Table 5). The negative effect of Phytophthora inoculation on the growth of strawberries was significant in the control and the growing medium-amended sewage sludge compost, but not in manure/wood fiber compost-amended growing medium (Fig. 3). This supports our prediction that manure/wood fiber compost is more disease suppressive than the sewage sludge compost. Pairwise comparisons (Fig. 4) within composts show that none of the microbes had an impact on strawberry growth on sewage sludge compost and that Pseudomonas fluorescens had no effect on any of the composts. However, Myko-Ymppi alone and also together with Pseudomonas had significant dry matter increasing effects on both the control growing medium and manure/wood fiber compost medium.

The sewage sludge compost containing growing medium caused the best overall growth response (Fig. 3) which may explain why the minor growth promoting impacts of microbes were not significant. The plants grown

Table 5

Mixed model analysis of dry weight variance of the third experiment

\begin{tabular}{lccc}
\hline Variable & df & F-value & $P$-value \\
\hline Compost & 10 & 23.74 & 0.0002 \\
Microbial treatment & 105 & 24.63 & $<0.0001$ \\
Phytophthora & 105 & 45.89 & $<0.0001$ \\
Compost*Microbial treatment & 105 & 4.07 & 0.0010 \\
Compost*Phytophthora & 105 & 5.37 & 0.0060 \\
Compost*Microbial treatment*Phytophthora & 105 & 1.20 & 0.3037 \\
\hline
\end{tabular}

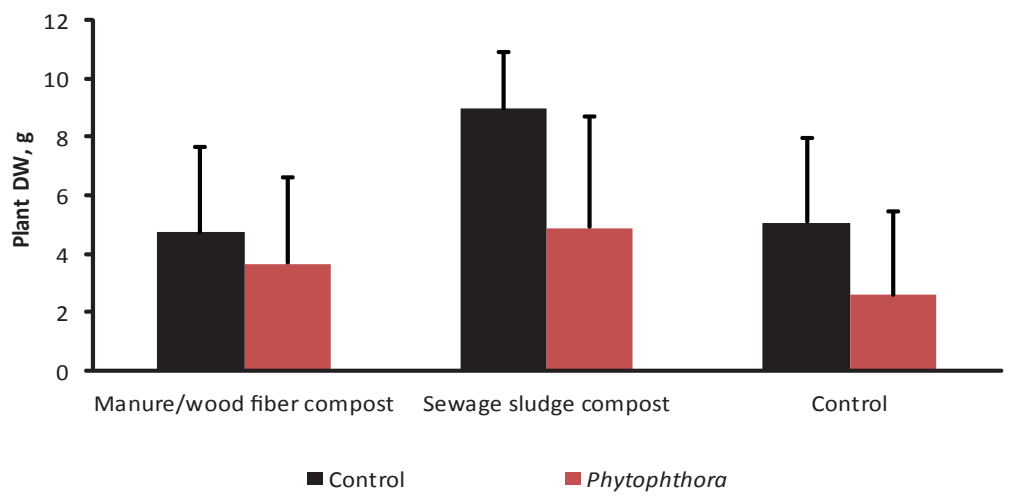

Fig. 3. The impact of Phytophthora inoculation on strawberry shoot dry weight (mean+std; $N=24$ ) on two growing media containing compost and in the control without compost (experiment 3, see Tables $1 \& 2$ ). The results are means of three microbial and a control treatment. The differences between Phytophthora-inoculated and controls were significant on sewage sludge compost containing growing medium $(\mathrm{df}=105, \mathrm{~F}$-value $=6,28, P<0.0001)$ and on the control growing medium $(\mathrm{df}=105, \mathrm{~F}$-value $=3,81, P=0.0031)$. 


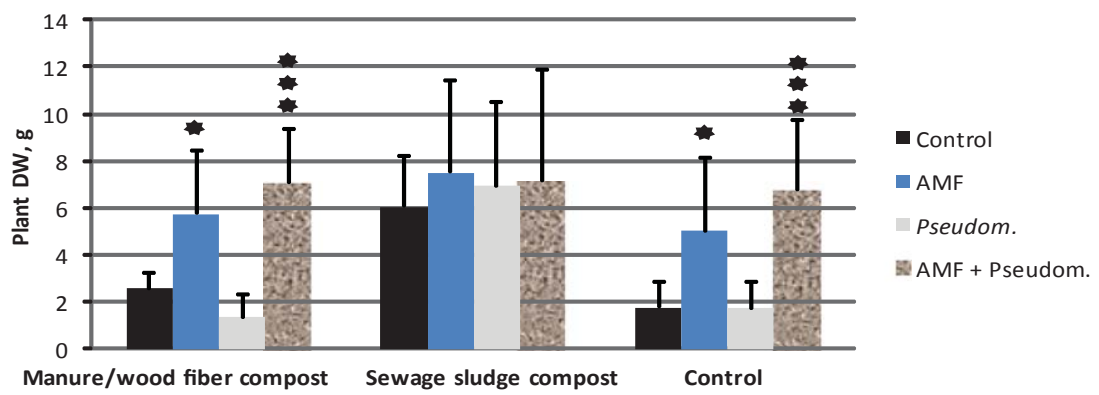

Fig. 4. The impact of microbial inoculation on strawberry shoot dry weight (mean+std; $N=12$ ) on two growing media containing compost and in the control without compost ((experiment 3, see Tables $1 \& 2$ ). The results are means of Phytophthora-inoculated and non-inoculated. $\star=$ significantly different from control treatment at $p<0.05, \star \star \star=$ significantly different from control treatment at $p<0.001$.

on sewage sludge compost are however strongly affected by Phytophthora inoculation (growth reduction of around $50 \%$ in microbe treated and diseased plants), which suggests that it contains only low or no disease controlling impact of microbes. The weak performance of the treatments Myko-Ymppi and Myko-Ymppi + P. fluorescens (Figs. 1,4) in the growing medium containing sewage sludge compost may be due to the high nutritional level of the compost, which may have caused negative mycorrhizal impacts despite root colonization exceeding $80 \%$ (results not shown). Different performance of composts may also be due to their immaturity [40]. Although the composts used in the study differed in age, they were both mature. Several methods have been suggested for improving the disease suppressing abilities of composts such as inoculation of compost with specific antagonists [41] or wet sieving biowaste prior to composting [42]. Our findings give support to positive compost*microbe interactions, i.e. some microbe treatments promote growth on some composts.

Phytophthora inoculation had no significant impact on the interaction between microbes and composts so the influence of microbes on plant dry weight in different composts did not significantly change whether there was Phytophthora present or not. However, there were indications that all microbial treatments caused an increase in disease severity especially on the sewage sludge compost containing growing medium (results not shown).

\subsection{General discussion of results}

Proper mycorrhizal colonization is essential for biological control by AMF [43]. In our experiments the AMF root colonization mostly exceeded $70 \%$ which should be sufficient for biological control. In Experiment 1, however, the AMF strain V307 clearly caused lower root colonization on growing media A (35\%) and B (30\%) compared to $\mathrm{C}(74 \%)$, but this could not be seen from the results.

The experiments in this study were conducted as separate pot experiments and therefore only indicate the potential field performance of biological protection. Longer field experiments should be carried out to ensure effective levels of disease outbreaks and to be able to observe the interactions of the biological control agents and the environment. Porras et al. [44] reported a clear decrease of Phytophthora cactorum and increase of the control agent Trichoderma spp. within a period of nearly three years.

The mycorrhizal strains clearly hindered the development of disease symptoms in Experiment 1 and MykoYmppi also significantly enhanced plant growth in two out of three growing media used in Experiment 3. This variation in AMF effect has been reported also from our previous experiments [13, 34]. One explanation for the variation in mycorrhizal effectiveness is the differences in the growing media that led to different plant-microbe and microbe-microbe-interactions in the growing media. The overall fluctuating nature of the biological control and growth impact between experiments is commonly known and was reported in our previous experiment [13] as well. Several authors offer the combination of microbes as a solution for this fluctuation [38]. However the only 
result that supported this hypothesis in our study was the finding that Pseudomonas fluorescens and Myko-Ymppi together resulted in as good growth as Myko-Ymppi alone, which suggests that they were compatible.

\section{Conclusions}

Arbuscular mycorrhizal fungi and especially "Myko-Ymppi" showed promising growth promoting and biological control abilities, but these effects were growing-medium-specific and could not be generalized in all conditions. Biological disease management was not achieved in these experiments with the help of single, dual or multimicrobial inoculation, but was rather achieved with the help of a suitable growing medium containing disease suppressive compost. Plant growth measured as the difference in dry matter accumulation between Phytophthora-inoculated and non-inoculated plants was the most informative variable in these experiments. Results from experiments carried out during different seasons (early-summer vs. late-summer or autumn) are difficult to compare because conditions during different seasons are not always optimal for disease inoculation and function of microbial inoculants. Mycorrhizal inoculation and compost amendment had a promising influence on plant growth and therefore this should be studied more.

\section{Acknowledgments}

This study was supported financially by the EUBerry project "EU FP7 KBBE-2010-4 Grant Agreement number 265942". Skillful technical assistance is also acknowledged for the proficient conduction of the experiments. In particular, our special thanks go to Marjaana Virtanen working at Luke in Jokioinen and Jaana Ala-Kaarre working at Luke in Piikkiö.

\section{References}

[1] Mass JL. Compendium of Strawberry Diseases. American Phytopathological Society. St.Paul, Minnesota; 1984.

[2] Deutschmann VF. Eine Wurzelfäule an Erdbeeren hervorgerufen durch Phytophthora cactorum (Leb. et Cohn) Schroet. Nachrichtenbl Deutsch Pflanzenschutzd. 1954;6:7-9.

[3] Parikka P. Phytophtora cactorum on strawberry in Finland. Nordisk Jordbruksforskning. 1991;73:121.

[4] Montreal protocol, United Nations Environment Program; 1989.

[5] Martin FN. Development of alternative strategies for management of soilborne pathogens currently controlled with methyl bromide. Annu Rev Phytopathol. 2003;41:325-50.

[6] Parikka P. Screening of strawberry resistance to Phytophthora cactorum. Sodininkyste ir Darzininkyste. 2007;26:23-30.

[7] Schüßler A, Schwarzott D, Walker C. A new fungal phylum, the Glomeromycota: Phylogeny and evolution. Mycol Res. 2001;105:141321.

[8] Smith SE, Read DJ. Mycorrhizal Symbiosis. 2nd ed. Academic Pres,San Diego and London; 1997.

[9] Olawyi OJ, Odebodea AC, Oyewole IO, Akanmu AO, Afolabi O. Effect of arbuscular mycorrhizal fungi on Pythium aphanidermatum causing foot rot disease on pawpaw (Carica papaya L.) seedlings. Arch Phytopathol Pl Prot. 2014;47:185-93. DOI $10.1080 / 03235408.2013 .806079$

[10] Larsen J, Graham JH, Cubero J, Ravnskov S. Biocontrol traits of plant growth suppressive arbuscular mycorrhizal fungi against root rot in tomato caused by Pythium aphanidermatum. Eur J Plant Pathol. 2012;133:361-69. DOI 10.1007/s10658-011-9909-9

[11] Norman JR, Hooker JE. Sporulation of Phytophthora fragariae shows greater stimulation by exudates of non-mycorrhizal than by mycorrhizal strawberry roots. Mycol Res. 2000;104:1069-73.

[12] Mark GL, Cassells AC. Genotype-dependence in the interaction between Glomus fistulosum, Phytophthora fragariae and the wild strawberry (Fragaria vesca). Plant Soil. 1996;185:233-9.

[13] Vestberg M, Kukkonen S, Saari K, Parikka P, Huttunen J, Tainio L, Devos N, Weekers F, Kevers C, Thonart P, Lemoine M-C, Cordier C, Alabouvette C, Gianinazzi S. Microbial inoculation for improving the growth and health of micropropagated strawberry. Appl Soil Ecol. 2004;27:243-58. 
[14] Hessenmüller A, Zeller W. Biologishe Bekämpfüng von bodenbürtingen Phytophtora-Arten an Erdbeere durch bakterielle Antagonisten. 1. Antagonistische Wirktung und Kolonisierung der Rhizoplane. Z Pfl Krankh Plf Shutz. 1996;103:602-9.

[15] Gulati MK, Koch E, Sikora RA, Zeller W. Biological control of Phytophthora diseases on strawberry with rhizobacteria. IOBC wprs bulletin International organization for biological control, IOBC. Montfavet. 2001;24(1):51-55.

[16] Anandhakumar J, Zeller W. Biological control of red stele (Phytophthora fragariae var. fragariae) and crown rot (P. cactorum) disease of strawberry with rhizobacteria. J Pl Dis Prot. 2008;115:49-56.

[17] Agusti L, Bonaterra A, Moragrega C, Camps J, Montesinos E. Biocontrol of root rot of strawberry caused by Phytophthora cactorum with a combination of two Pseudomonas fluorescens strains. J Pl Pathol. 2011;363-72.

[18] Kukkurainen S, Leino A, Vähämiko S, Kärkkäinen HR, Ahanen K, Sorvari S. Occurence and location of endophytic bacteria in garden and wild strawberry. Hortic Sci. 2005;40:348-52.

[19] Toldi O, Sorvari S. Endophytic Pseudomonas fluorescens provides resistance to fungal pathogens in strawberry. In: Karhu S, editor. Sadonkorjuu - Tutkittua puutarhatuotantoa 2003-2005: Harvest - Horticultural Research Results 2003-2005. MTT: N Selvityksiä. 2007;139:79.

[20] Vestberg M, Kukkonen S, Rantala S, Prochazka P, Tuohimetsä S, Setälä H, Romantschuk M, Kurola J, Yu D, Parikka P. Suppressiveness of Finnish commercial compost against soil borne disease. Acta Hort. 2011;891:59-65.

[21] McKellar E, Nelson EB. Compost-induced suppression of Pythium damping-off is mediated by fatty-acid-metabolizing seedcolonizing microbial communities. App Environ Microb. 2003;69:452-60.

[22] Hoitink HAJ, Boehm MJ. Biocontrol within the context of soil microbial communities: A substrate-dependent phenomenon. Annu Rev Phytopathol. 1999;37:427-46.

[23] Suarez-Estrella F, Vargas-Garzia C, Lopez MJ, Capel C, Moreno J. Antagonist activity of bacteria and fungi from horticultural compost against Fusarium oxysporum f.sp.melonis. Crop Protection. 2007;26:46-53.

[24] Garcia C, Hernandes T, Costa F, Pascual JA. Phytotoxicity due to the agricultural use urban wastes. Germination experiments. J Sci Food Agric. 1992;59:313-19.

[25] Hoitink HAJ, Zuniga de Ramos L. Disease suppression with compost; history, principles and future. 1st International Conference of soil and compost eco-biology. September 15th-17th 2004, León - Spain. Available online: http://www.soilace.com/ pdf/pon2004/15.Hoitink.pdf. Cited 15.9.2014.

[26] Zhang W, Dick W, Hoitink HAJ. Compost-induced systemic acquired resistance in cucumber to Pythium root rot and anthracnose. Phytopathology. 1996;86:1066-70.

[27] Alabouvette C, Olivain C, Cordier C, Lemanceau P, Gianinazzi, S. Enhancing biological control by combining micro-organisms. In: Vurro M, editor. Enhancing Biocontrol Agents and Handling Risks. Vol 339. IOS Press 2001.

[28] Giovannetti M, Mosse B. An evaluation of techniques for measuring vesicular arbscular mycorrhizal infection in roots. New Phytol. 1980;84:489-500.

[29] Phillips JM, Hayman DS. Improved procedures for clearing and staining parasiticand vesicular arbuscular mycorrhizal fungi for rapid assessment of infection. Trans Brit Mycol Soc. 1970;55:158-61.

[30] King EO, Ward MK, Raney DE. Two simple media for the demonstration of pyocyanin and fluorescin. J Lab Clin Med. 1954;44:301-7.

[31] OECD 2008. OECD Guideline for the testing of chemicals No 226. Predatory mite (Hypoaspis (Geolaelaps) aculeifer) reproduction test in soil. Organization for Economic Cooperation and Development. Paris. DOI 10.1787/9789264067455-en

[32] Vestberg M, Kukkonen S. Microbiologically improved peat-based media for nursery production by addition of arbuscular mycorrhizal fungi. Acta Hortic. 2009;819:403-10.

[33] von Alten H, Blal B, Dodd JC, Feldmann F, Vosatka M. Quality control of arbuscular mycorrhizal fungi in Europe. In: Gianinazzi S, Schüepp H, Barea JM, Haselwandter K, editors. Mycorrhizal technology in agriculture. Switzerland: Birkhäuser; 2002 , pp. 296.

[34] Vestberg M, Palmujoki H, Parikka P, Uosukainen M. Effect of arbuscular mycorrhizas on crown rot (Phytophthora cactorum) in micropropagated strawberry plants. Agric Sci Finl. 1994;3:289-95.

[35] Rosenblueth M, Martínez-Romero E. Bacterial endophytes and their interactions with hosts. Mol Plant Microbe Interact. 2006;19(8):827-37.

[36] Davis RM, Menge JA. Influence of Glomus fasciculatus and soil phosphorus on Phytophtora root rot of citrus. Phytopathology. 1980;70: 447-52.

[37] Vestberg M, Kukkonen S, Uosukainen M. Occurrence and Effectiveness of Indigenous mycorrhiza of some strawberry fields in Finland. Acta Hort. 2002;567:499-502.

[38] Hoitink HAJ, Stone AG, Han DY. Suppression of plant diseases by composts. Hort Sci. 1997;32:184-87.

[39] Zhang W, Dick W, Hoitink HAJ. Compost-induced systemic acquired resistance in cucumber to Pythium root rot and anthracnose. Phytopathology. 1996;86:1066-70. 
[40] Hoitink HAJ, Krause MS, Han DY. Spectrum and mechanisms of plant disease control with composts. In: Stoffella DJ, Kahn BA, editors. Compost utilization in horticultural cropping systems. Washington DC: Lewis Publishers; 2001, pp. 430.

[41] Hoitink HAJ and Boehm MJ. Biocontrol within the context of soil microbial communities: A substrate-dependent phenomenon. Annu Rev Phytopathol. 1999;37:427-46.

[42] Azcón-Aguilar C, Jaizme-Vega MC, Calvet C. The contribution of arbuscular mycorrhizal fungi to the control of soil-borne plant pathogens. In: Gianinazzi S, Schüepp H, Barea JM, Haselwandter K, editors. Mycorrhizal technology in agriculture. Switzerland: Birkhäuser; 2002, pp. 296.

[43] Veeken AHM, Blok WJ, Curci F, Coenen GCM, Termoshuizen AJ, Hamelers HVM. Improving quality of composted biowaste to enhance disease suppressiveness of compost-amended, peat-based potting mixes. Soil Biol Biochem. 2005;37:2131-40.

[44] Porras M, Barrau C, Romero F. Effects of soil solarization and Trichoderma on strawberry production. Crop Prot. 2007;26:782-87. DOI 10.1016/j.cropro.2006.07.005 